Bryn Mawr College

Scholarship, Research, and Creative Work at Bryn Mawr College

Classical and Near Eastern Archaeology Faculty

Research and Scholarship

Classical and Near Eastern Archaeology

1969

\title{
Two Peplophoroi in the United States
}

Brunilde S. Ridgway

Bryn Mawr College, bridgway@brynmawr.edu

Let us know how access to this document benefits you.

Follow this and additional works at: http://repository.brynmawr.edu/arch_pubs

Part of the Classical Archaeology and Art History Commons, and the History of Art, Architecture, and Archaeology Commons

\section{Custom Citation}

Ridgway, Brunilde S. 1969. Two Peplophoroi in the United States. Hesperia 38:213-222.

This paper is posted at Scholarship, Research, and Creative Work at Bryn Mawr College. http://repository.brynmawr.edu/arch_pubs/2

For more information, please contact repository@brynmawr.edu. 


\section{TWO PEPLOPHOROI IN THE UNITED STATES}

\section{(Plates 54-57)}

T can hardly hope to present Professor Carpenter with new ideas on Greek Sculpture, 1 since he taught me everything I know in this field. I am therefore forced to fall back on the relative novelty of the two pieces which the respective Museum Curators have so generously allowed me to publish here.

The first is the slightly under life-sized statue of a Severe style peplophoros in the Walters Art Gallery, Baltimore (P1. 54, a, 55, a, 56, a, d, 57). ${ }^{1}$ It once belonged to the Hope Collection in Deepdene, England, and as such is listed in Michaelis and Reinach; it has also received brief mentions and illustrations elsewhere, ${ }^{2}$ but never the full and detailed description it deserves.

The statue represents a woman standing upright with her left foot slightly advanced, her right arm outstretched, and her left hand holding aside the skirt of her peplos (P1. 54, a). The head (P1. 57), though ancient, belongs to a different artistic current; though Michaelis considered it pertinent, it should be dissociated from the body on account not only of its style but also of its marble, which varies in color and grain from the rest of the statue. ${ }^{3}$ Likewise, the right hand and a good portion of the wrist are of a different material and do not belong. Modern restorations include a patch on the right forearm, the entire neck, a large portion of the drapery on the front of the skirt at approximately knee level, most of the outermost pleat on the proper left of the skirt, and minor patches in other folds. In all cases, however, the surrounding drapery retains the general pattern and makes restoration safe. ${ }^{4}$

${ }^{1}$ Inv. no. 23.87. Large-grained island marble. Height, from floor to top of head: $1.43 \mathrm{~m}$. (given by Michaelis as $1.36 \mathrm{~m}$.) ; from soles of feet to break in neck: $1.15 \mathrm{~m}$. Bought by Henry Walters through a dealer in 1930 and bequeathed by him to the citizens of Baltimore with the rest of his collection in 1931. I am deeply indebted to Dr. Dorothy Kent Hill, Curator of Ancient Art at the Walters Art Gallery, for allowing me to publish this piece.

In my text, right and left refer always to the statue's.

${ }^{2}$ A. Michaelis, Ancient Marbles in Great Britain, Cambridge, 1882, p. 285, no. 13.

S. Reinach, Repertoire de la Sculpture, 5, Paris, 1924, p. 367, no. 6.

Hope Sale Catalogue, Christie, 1917, p. 36, no. 234, pl. 12.

Gazette, 1921, p. 301 (mentioned by Reinach and Langlotz).

A. Raubitschek, B.S.A., XL, 1939-40, p. 36.

E. Langlotz, Jahrb., LXI-LXII, 1946-47, p. 105, pl. 26, 2.

E. Paribeni, Annuario, N.S., VIII-X, 1946-48, pp. 103-105, fig. 1.

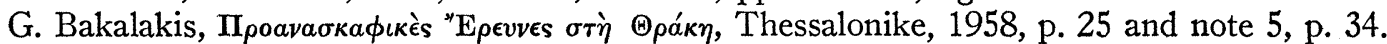

L. Forti, Le Danzatrici di Ercolano, Naples, 1959, pp. 24-25.

${ }^{3}$ Since the head is not pertinent, it will not be discussed in the present study. Its restorations include the nose with part of the upper lip and the lower part of the hair chignon over the nape.

${ }^{4}$ Other damages are as follows: the right arm broke off above the elbow, taking with it part of the drapery over the right flank; the piece has been reattached and must be the original fragment, 
The woman wears the belted peplos with kolpos and apoptygma, open on the right side (P1. 56, a) and fastened at the top by two long pins which were once inserted in metal, as two oval holes over each shoulder indicate. Other metal additions formed the straps of the sandals, the soles of which are indicated in stone. Four holes per foot, one on the upper surface near the edge of the drapery, one on the outside of the small toe, $^{5}$ and one on either side of the big toe, suggest that the bronze thongs created a cross pattern, similar to that of the sandals carved on Akropolis Kore 682. ${ }^{6}$ Two more pairs of holes, on the kolpos, are more difficult to explain. That they once held metal pins is indicated by the rusty staining of the marble, but Michaelis' suggestion that they supported a metal girdle is unlikely, since the belt must be visualized under the kolpos, not above. Moreover, the holes are not aligned, the pair on the proper left being set somewhat at a slant in respect to the pair on the right. ${ }^{7}$ Bronze rosettes seem out of place on a peplos, nor does the arrangement of the apoptygma require piecing for extra folds or separately carved additions. One might perhaps assume that the object once held by the right hand was in metal and stretched partly across to the front of the figure, so as to allow fastening at her waist. A sheaf of wheat or a fillet could probably satisfy these conditions, but the suggestion is not entirely convincing. Slight asymmetries occur here and there in the rendering of the figure: the right shoulder is shorter than the left and, perhaps in harmony with the advanced left foot, the edges of kolpos and apoptygma slant slightly toward that side. Only three front folds originate from the pin on the right shoulder, while four appear in the back and four on both sides of the left pin. The original head was presumably slightly turned

though the edges are clean and straight, since the marble is the same and presents the same discolorations as the surrounding areas. Part of the back below the nape must have broken off when the original head was lost, but has been reattached, in two pieces. The corresponding damage over the front, above the collarbones, is simply hidden by plaster to the point where it meets the modern, improbably smooth, neck. A crack crosses the left foot; a blow below the buttocks has removed parts of the ridges of four folds, and chips appear in several others; the break which required the modern patch over the skirt front has split the statue in two, but the back retains a true joint. The plinth of the statue is the original, but the base is modern.

${ }^{5} \mathrm{~A}$ hole in front of the tip of the right small toe is not paralleled in the other foot and seems never to have contained a metal fastening. It was probably a carving mistake.

${ }^{6} \mathrm{H}$. Schrader, Die archaischen Marmorbildwerke der Akropolis, Frankfurt, 1939, pl. 57, detail of feet. For such sandals on a Severe statue see the Peplophoros in the Villa Borghese, BrBr 261.

${ }^{7}$ It could be assumed that the flat strip of marble visible under the apoptygma is not the kolpos but the belt itself, once covered with metal. This arrangement would however be unique in peplophoroi, and seems disproved by the treatment of the back, where the "band" is wider. Nor could the holes be for a Herculean knot in metal, since in that case only one set would be necessary, or even a single hole. Two marble strips for the belt ends are also unlikely, since a peplos is generally belted either over the apoptygma or well under it, not at its edge. Even the unusual bronze statuette in the Bibliothèque Nationale, Paris (G. M. A. Richter, Sculpture and Sculptors of the Greeks, New Haven, 1950, fig. 318) has a different arrangement of the hanging ends of the belt, itself invisible under the kolpos. 
to the proper right, like the "replacement head" at present on the body; though not even the ends of the sternomastoids are preserved, this position is suggested by the rendering of the entire figure and especially of the back.

In fact, though from the front the statue appears fully frontal, a surprising torsion is actually detected from other points of view. The right profile (P1. 56, a) is especially revealing: the lower part of the body seems to move forward with the advanced leg, thus turning to that side, but at hip level a shift occurs, in keeping with the outstretched right arm which apparently pulls the shoulder in that direction. This impression is enhanced by the treatment of the scapulae which, though rendered only as general mass on either side of the spinal furrow, differ in volume, the left one seemingly higher and more pronounced.

The appearance of the drapery also varies according to the viewpoint. Directly from the front (P1. 54, a) or the back (P1. 55, a), the steep vertical folds of the skirt are seen to be clearly separated by deep and fairly wide grooves, especially marked in the rear, which lend the figure a columnar aspect; a three-quarter position from either right or left reveals only the tops of the ridges and conceals the intervening grooves, with a surprisingly plastic effect. A certain plasticity is evident also in the folds of the apoptygma under and behind each arm, combined with a degree of undercutting which contrasts with the flat linearity of the zigzags both at front and back. Surprisingly flat is also the straight kolpos (which in no way reveals its double thickness of layers) as against the bulging " eye-folds" just below it.

Indeed a strange dichotomy of treatment exists between the upper and lower part of the figure. Above the kolpos everything is smooth and solid. The cloth adheres tightly to the rounded abdomen and the projecting breasts, without slackness even at the neckline which closely follows the contour of the collar bones. The vertical folds originating from the shoulder pins are toned down and curve slightly in toward the waist, swinging out again over the hips. But below this level the underlying bodily structure disappears entirely and the surface is fractioned into a series of uniform flutes. The columnar effect is respected to the point that the skirt, though held aside by the left hand, does not flare out at the bottom, nor does it cling to the legs but even tapers toward the feet, while the outermost fold on the proper left slants inward with surprising behavior.

Other peculiarities then become apparent. Viewed in profile, the skirt does not hang stiffly in front of the legs with the starched appearance of many Severe statues, but caves in as if following the contour of thighs and shins. Yet the sculptor has given no indication of the knees, not even for the presumably advanced leg, with a surprising disinterest in the problems of stance and balance. Because of this concave treatment of the skirt the statue is too thin at approximately knee level, where indeed it broke. The skirt is shorter at the front than at the back, presumably because it is being pulled aside and forward, but this gesture cannot explain the wide exposure of the feet which protrude from under the cloth as if disembodied, while the garment 
dips and rises around them with an effect reminiscent of the early Archaic Berlin Kore. Likewise, the tightly fitting overfold finds a close parallel only in a sixth century statue, the so-called Peplos Kore.

The back (P1. 55, a) too, though not the most important aspect of the statue, presents some incongruences. The garment clings to the spinal furrow with the same tautness of the front, as if it were in a single layer, and even the fluted skirt adheres to the glutei in a fashion which once again recalls Archaic renderings. Finally, the back panel of the apoptygma seems too small in proportion to the corresponding panel over the front, ${ }^{9}$ and both seem small in proportion to the general composition.

How can we interpret all these strange features? The workmanship of the Hope peplophoros is so good, the use of the drill so moderate and well dissimulated, the general appearance so pleasing, that at first the statue may even be considered a Greek original of the early Severe period, around 475 B.C. But the harshness of the grooves, the naturalism of the surviving hand (notice the creases at the bends of the finger and the rendering of the soft padding of the palm ${ }^{10}$ ), the contrast between linearity and plasticity suggest a later date of manufacture. Should the piece therefore be labelled a Roman copy and all its discrepancies be imputed to the careless copyist?

If this were the case, the Hope Peplophoros should fit well within the series of Roman replicas of Severe prototypes. Indeed most of the statuary of the early fifth century must have been of bronze, and therefore the majority of Severe masterpieces has survived for us only in later Roman reproductions. Yet next to such famous works as the Hestia Giustiniani, the Ludovisi Goddess, the Peplophoros in Copenhagen, the Peplophoros from Castel Sant' Angelo, the Peplophoros Borghese, all typologically related to the Hope maiden, this latter strikes an entirely different note. ${ }^{11}$

${ }^{8}$ Berlin Kore: R. Lullies and M. Hirmer, Greek Sculpture, New York, 1960, pl. 21. Technically, the feet of the Hope peplophoros have been carved separate only up to the level of the skirt, under which they are left in an undivided mass, as visible also from the back; the outer contours of the sandals are rendered only at the sides. Peplos Kore: Lullies and Hirmer, op. cit., pls. 43-44.

${ }^{9}$ An even narrower back panel appears on the so-called Hestia Giustiniani (Richter, op. cit., fig. 257), but presumably because conditioned by the veil pattern. The modelled spinal furrow occurs on the Copenhagen Peplophoros (ibid., fig. 321) but accompanied by converging modelling folds.

${ }^{10}$ Even the realistic fold of Athena's left hand in the Augeian Stables metope at Olympia, to which Ashmole has called attention (B. Ashmole and N. Yalouris, Olympia, Phaidon Press, 1967, p. 29, fig. 204), seems stylized in comparison.

${ }^{11}$ Hestia Giustiniani: $\mathrm{BrBr} 491$.

Ludovisi Goddess (so-called Candia Type): E. Paribeni, Sculture Greche del V Secolo, Museo Nazionale Romano, Rome, 1953, fig. 89.

Copenhagen Peplophoros: Richter, op. cit., figs. 320-321; also E. Buschor and R. Hamann, Die Skulpturen des Zeustempels zu Olympia, Marburg, 1924, fig. 22.

Peplophoros from Castel Sant'Angelo: Buschor and Hamann, op. cit., figs. 21-22; also Paribeni, Sculture V Secolo, fig. 82, a-b.

Peplophoros Borghese: $\operatorname{BrBr} 261$; also W.-H. Schuchhardt, Die Epochen der griechischen Plastik, Baden-Baden, 1959, fig. 46 opposite p. 56. 
Her narrow downward tapering outline contrasts with the spreading skirts of the others, her smooth apoptygma with their modelled overfolds, each characterized by a more or less elaborate pattern of folds. Moreover, since the Hope maiden's overfold clings to her body, it fails to form that wide rectangular panel which so emphatically marks the upper part of the other compositions like a stiff, if somewhat short, " maternity top." Her kolpos entirely lacks the swollen, folded appearance of the others, her apoptygma has too little projection to determine a definite accent at the waist. Most Severe peplophoroi disarray the pattern of their skirts by bending or moving a leg sideways, so that the folds flatten or at least widen over the advanced limb; the Hope maiden moves her left foot forward but nothing happens in the leg area to the steep pleats of her dress. The most columnar of the Roman copies, the Hestia Giustiniani and the Castel Sant' Angelo Peplophoros, show no indication of the legs, but their feet are not so prominent under the skirt ${ }^{12}$ and their lower bodies are considerably thicker than those of the Baltimore statue.

If these considerations apply to Roman copies, they are even more relevant for Greek originals, such as Angelitos' Athena or the peplophoroi from the metopes and the East pediment of the temple of Zeus at Olympia. Their apoptygmas are always enlivened by oblique or curved folds, their skirt patterns are always more or less irregular. A Thracian peplophoros, who almost exaggerates the motif of the columnlike skirt, has soft catenaries in her overfold. Ionic peplophoroi, who wear their costume unbelted, like a chiton, and let it cling to the body, may compare with the Hope maiden in their overall smoothness of forms, but their salient anatomical points are thus revealed and their fluid appearance lacks the clear divisions and vertical accents of the Baltimore statue. ${ }^{13}$ These Ionic peplophoroi, like the Hope maiden, hold their skirts aside, a pose most popular in the Archaic period which presumably originated in East Greece. It is therefore natural to find that the motif lingered there when it had been superseded elsewhere, yet it was generally exploited to reveal the body or to create looping catenaries on an otherwise unrelieved expanse of marble. In the Baltimore figure the gesture has no effect on the basic pattern and remains an isolated manerism. ${ }^{14}$

${ }^{12}$ The back view of the Hestia Giustiniani (Richter, op. cit., fig. 257) shows however the presence of the left leg in the irregularity of the skirt folds. The protrusion of the feet seems paralleled only in mirror supports (on which see infra) perhaps because of a need for explicit stability. But I know of no exact parallels in large-scale statuary. Even comparison with a male figure fails to clarify this point: if the skirt of the Delphi Charioteer is prolonged on paper to reach his feet, much less of them remains exposed.

${ }_{13}$ Angelitos' Athena $=$ Akr. 140: Schrader, op. cit., pls. 9-10; Olympia sculptures: Ashmole and Yalouris, op. cit., passim. Thracian Peplophoros: G. Bakalakis, op. cit., pp. 19-42. Ionic peplophoroi : from Xanthos, British Museum B 316-318, Pryce, Brit. Mus. Catalogue; also Buschor and Hamann, op. cit., figs. 18-19.

Nike from Paros: ibid., fig. 17; EA 2395-2398.

${ }^{14}$ This gesture often appears in small mirror-supports in bronze, unquestionably Greek originals of the early fifth century, in combination with the fluted skirt. (See e.g., E. Langlotz, Frueh- 
E. Paribeni, in publishing a female torso from Piazza Barberini in Rome, established a parallel with the Hope peplophoros, which he considered a product of the same Magna Graecian artistic center, though a decade or two later than the Roman piece. The Italian scholar believed that the many linear catenaries of the Barberini apoptygma were an index of early date which had "disappeared" by the time of the Baltimore figure, giving place to a more "severe" flatness. ${ }^{15}$ But should the theory be reversed instead? It would be more logical to find smooth and undetailed renderings in early works, superseded by an interest in modelling folds and catenaries toward the end of the Severe phase: witness the Nike akroterion from the Athenian Agora or the Pitcairn Nike in Philadelphia, both types to be dated around 440 B.C. Also the rounded edge of the Barberini apoptygma can be paralleled in late Severe pieces, e.g., the Running Maiden from Marmaria (Delphi). ${ }^{16}$ Paribeni's early dating was presumably influenced by the gesture of the Barberini peplophoros, holding her skirt aside like an Akropolis kore; here, however, in contrast with the Hope maiden, the folds acknowledge the movement by forming long curving lines. Unfortunately the Barberini statue is broken off just below the knees, and it is impossible to follow the development of the skirt rendering down to the feet.

Besides the specific treatment of this gesture and the elaborate modelling of the overfold, the Barberini differs from the Baltimore peplophoros also in the carving of the vertical folds, which in the former are mostly rounded ridges divided by thin shallow grooves, while in the latter the grooves are deeper and wider and a more integral part of the composition. Yet Paribeni correctly detected a basic affinity within the two figures which he attributed to a common origin in a provincial center with a lingering Archaic tradition. I would rather ascribe it to the fact that both are "Classicizing" works created during the first century B.c.

Paribeni, aware of this possibility, eloquently defended the Barberini torso against the accusation of being a "literary creation." Yet other works involved in his defense are generally accepted as Archaistic or Classicizing, e.g., the Kore Albani or

griechische Bildhauerschulen, Nuernberg, 1927, pls. 15-17, 23, 33, 47, 73; V. Poulsen, Der strenge Stil, Copenhagen, 1937, figs. 11-18; D. G. Mitten and S. F. Doeringer, Master Bronzes from the Classical World, Cambridge, Mass., 1967, nos. 87-88; cf. also no. 90.) However, all these figures show an interest in bodily forms and balance, with a resultant asymmetry of the vertical folds or, even if the skirt remains columnar, a more plastic modelling of the apoptygma. The mannerism of the lifted skirt, moreover, is more understandable in the minor arts than in large-scale sculpture.

${ }^{15}$ E. Paribeni, "Un Torso di Peplophoros da Piazza Barberini," Annuario, N.S., VIII-X, 1946-48, pp. 99-107; see p. 104 for the quotation. By the same author, see also Sculture $V$ Secolo, fig. 79.

${ }^{16}$ Nike akroterion from the Athenian Agora = Athens Nat. Mus. no. 1732: Richter, op. cit., figs. 725-726.

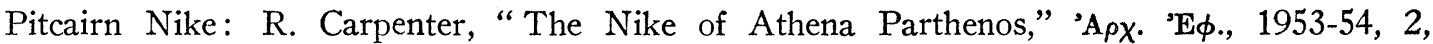
Festschrift Oikonomos, pp. 41-55, pls. 1-2. Running Maiden from Marmaria: Richter, op. cit., fig. 89, dated ca. $460-450$ on p. 63. See, however, J. Marcadé, “ Sculptures inédites de Marmaria," B.C.H., LXXIX, 1955, pp. 417-418, fig. 28, who dates the figure ca. 470 B.C. 
the Guicciardini Kore. ${ }^{17}$ Paribeni assumed that the Roman peplophoros belonged to a small number of Roman statues which copied Early Classical works for specific religious purposes, to replace an earlier and venerated cult image. This theory may perhaps explain the lack of other replicas, but is not sufficient to explain the peculiar qualities of these "copies." Archaistic creations of the first century B.c. to first century after Christ have long been recognized and accepted because of their obviously ornamental character and exaggerated mannerism; but modern scholarship has found it harder to accept that the Severe style of the early fifth century was also popular among Neo-Attic or "Pasitelean" artists, and that many works currently considered copies of Early Classical prototypes are indeed "Classicizing" originals. The dispute can still rage over the Runner in the Vatican, the Ephebe from Via dell' Abbondanza in Pompeii, the Esquiline Venus, the Spinario, the Mantua Apollo type, and even such a commercial decorative group as the Herculaneum Dancers. Yet all of these should be considered compositions made in Severe style but not during the Severe period, as attested by the mixture of "advanced" and " retarded" traits evident in all. ${ }^{18}$ The Hope Peplophoros finds her proper environment among them; indeed L. Forti, in studying the Herculaneum Dancers, has already expressed the opinion that the Baltimore statue is " Archaistic." 19

The true nature of the Hope Peplophoros can perhaps be best highlighted by comparison with a Severe original which strongly resembles it in general typology. This second statue is also little known, though of great importance, and, like the

${ }^{17}$ Kore Albani: $\mathrm{BrBr} 651$.

Guicciardini Kore: R. Bianchi Bandinelli, Critica d'Arte, VI, 1941, pp. 91-96.

${ }^{18}$ Runner in the Vatican: $\operatorname{BrBr} 521$; B. S. Ridgway, "The Bronze Apollo from Piombino in the Louvre," Antike Plastik, VII, 1967, p. 60, figs. 20-21. fig. 177.

Ephebe from Via dell' Abbondanza: G. M. A. Richter, Ancient Italy, Ann Arbor, 1955,

Esquiline Venus: R. Carpenter, M.A.A.R., XVIII, 1941, pp. 30-35; Richter, Ancient Italy, figs. 168-171.

Spinario: R. Carpenter, op. cit., pp. 35-41.

Mantua Apollo type: C. Saletti, "L’Apollo Citaredo di Pompei," Arte Antica e Moderna, 1960, pp. 248-262.

Herculaneum Dancers: L. Forti, Le Danzatrici di Ercolano, Naples, 1959; also BrBr 294-295.

For a recent defense of a true Severe chronology for many of these monuments see Richter, Ancient Italy, pp. 44-55. A discussion upholding the opposite point of view will be found in Ch. 9 of my forthcoming book on The Severe Style in Greek Sculpture. See also my comments in Antike Plastik, VII, 1967, pp. 58-62 with bibliography.

${ }^{19}$ Forti, op. cit., p. 25. She, however, accepts the Barberini Peplophoros as a genuine copy of a Severe original; I have not seen the statue personally and therefore my opinion is based on photographs. Note that some of the Herculaneum Dancers are built to be viewed from a diagonal point of view, a trait which Forti considers typical of Italian and Classicizing art (pp. 50-54, 59-60 and 67 with bibliography). The same seems to hold true for the Hope Peplophoros.

It should be pointed out that Michaelis had also considered the statue Archaistic, but he was probably influenced by the head which he believed pertinent. 
Hope maiden, was acquired by an American from an English private collection. It once formed part of the ancient marbles gathered by Lord Elgin in his Scottish residence at Broomhall (Fife), and is now in the J. Paul Getty Museum in Malibu, California (Pls. 54, b, 55, b, 56, b, c).$^{20}$ Seen by Michaelis too late to be included in his book on Ancient Marbles in Great Britain, the Elgin Peplophoros was published by him in volume $\mathrm{V}$ of the Journal of Hellenic Studies for 1884. Michaelis describes the torso as part of a relief "though nothing of the background has been preserved," but the extensive finish of the back (P1. 55, b) suggests that the sculpture was in the round and visible from all points. At Broomhall the piece had been embedded in a garden wall in such a way that Michaelis could not inspect it from the rear nor accurately judge its thickness. C. C. Vermeule, in his "Notes on a New Edition of Michaelis," refers to the torso simply as "fragment of an Archaic kore-type figure," and all other mentions of the work seem to take it for granted that it was free standing. ${ }^{21}$

${ }^{20}$ Inv. no. I-71. Large-grained grayish marble, probably from the Greek islands. Preserved height: $0.71 \mathrm{~m}$; overall width: $0.38 \mathrm{~m}$; thickness at the breast: $0.19 \mathrm{~m}$. This last dimension in Michaelis is given erroneously with the following comment: "the relief projects from the ground c. 0.09 measured at the breast," and should be explained on the basis of the setting of the statue at Broomhall. The other measurements in Michaelis are fairly accurate. I am most grateful to Dr. Burton B. Fredericksen, Curator of the J. Paul Getty Museum, for allowing me to publish this interesting piece, and for all his help in checking dimensions and providing photographs.

The statue is headless, the head having broken off at the base of the neck which however retains traces of the sternomastoids. Both arms were lowered and are broken off above the elbow; the right hand must have held the skirt of the peplos, as shown by the general composition; the left hand probably held an offering or an attribute. The right leg is broken off just below the knee, the other leg just above that point, along an oblique line of fracture. The edges of the folds are chipped and broken, in some areas exposing the cavity within the pleat. A large gash extending almost across the entire back and preserving tool marks could have been made in ancient times in an attempt to split the block, when the artistic value of the statue was no longer appreciated. However Dr. Fredericksen remarks that the cutting is too carefully done to be merely an attempt at splitting the statue. He suggests instead that it was made at Broomhall to diminish the projection of the right shoulder, making it flush with the buttocks to secure complete adherence to the wall. Since the left shoulder is more advanced than the right, the cutting was only extended part way. At the same time, and for the same fastening purposes, two tenons were inserted at the level of the scapulae and one in a large rectangular cavity behind the right knee. Dr. Hill however comments that cutting and metal bars suggest a pedimental origin for the Elgin statue, in which case they would be contemporary with its manufacture. She points out that a similar hole on the back of the Hope Peplophoros (now filled with plaster) might have served a similar purpose. But I am inclined to believe that neither statue stood in a pediment, and that all traces of fastening are modern. ${ }^{21}$ A. Michaelis, "Ancient Marbles in Great Britain-Supplement I," J.H.S., V, 1884, p. 145, no. 2 .

C. C. Vermeule, "Notes on a New Edition of Michaelis," A.J.A., LIX, 1955, p. 132. I am indebted to Professor Vermeule for the information on the setting of the torso at Broomhall.

E. Le Vane and J. P. Getty, Collector's Choice, London, 1955, p. 203 (Michaelis' text is quoted without further comments; illustration between pp. 192 and 193).

J. P. Getty Museum Guidebook, Malibu, California, 1954, pp. 22-23, no. 14 with plate.

J. P. Getty, Joys of Collecting, 1965, p. 46.

H. Stothart, A Handbook of the Sculpture in the J. Paul Getty Museum, 1965, pl. 13, p. 25. 
Though the Getty Handbook calls it Attic, the statue is of Island marble and would seem more at home in the Aegean area. Lord Elgin was mainly interested in the antiquities of Athens, but he is known to have collected inscriptions and reliefs from elsewhere, Cape Sigeion for instance, and his stay in Constantinople might have put him in contact with other antiquities from that general region. In keeping with this assumption is the peplophoros' gesture, though the general bulk of her body and the structural emphasis on verticals and horizontals would be more appropriate to a Peloponnesian work. ${ }^{22}$ Since the early fifth century was a period of great internationalism and increased traveling, the sculptural style current at the time enjoyed a wide diffusion, and it is particularly difficult to pinpoint regional traits or define schools. It is perhaps safer to consider the Elgin Peplophoros simply as a Greek original of the Severe period, as contrasted with the supposed Roman copy in Baltimore.

The two figures are almost mirror images, in that the Elgin maiden advances her right leg and holds her skirt on that side (P1. 56, c). But because of the real forward position of her leg, the cloth is grasped alongside the thigh, not awkwardly in front of it as in the Hope maiden. This gesture throws the vertical skirt folds into a variety of patterns, from layered pleats above the grasping point to engraved curves at the point itself to widened folds toward the inside of the leg ending in a smooth area above the prominent knee. Over the weight leg the folds are straight but not uniform, especially near the opening on the left side (Pl. 56, b). The grooves serve only to articulate the ridges, though near the waist some of the larger folds are subdivided by an extra furrow which does not extend for the entire length of the pleat. Some of these shorter grooves appear also in the Hope Peplophoros, lending the garment a bunched appearance and suggesting its soft consistency. The resultant " eye folds" are also found in other Severe works, for instance some of the Olympia peplophoroi from pediments and metopes, but in the Baltimore figure they are too regular and almost turgid, in the Elgin torso infrequent and somewhat too schematic.

Consonant with this basic simplicity, the latter's kolpos is kept entirely smooth, but undercutting and thickness convey true bulging and make it quite different from the flat band of the Baltimore statue. The apoptygma is a simple rectangle determined by the protruding breasts; though basically, and uncommonly, flat, still it waves with moderate plasticity at the lower edge and the sinking of its surface is graphically projected onto the scalloped hem line. In keeping with this block-like approach the

${ }^{22}$ Lord Elgin collected also from the Peloponnese and other areas in Greece. For an extensive account of his antiquarian activities see A. H. Smith, "Lord Elgin and his Collection," J.H.S., XXXVI, 1916, pp. 163-372, and especially pp. 182-183 for mention of pieces from Sigeion. A briefer report with main emphasis on the Elgin marbles in the British Museum appears in D. E. L. Haynes, An Historical Guide to the Sculptures of the Parthenon, London, 1962. Michaelis, loc. cit., suggests that the antiquities at Broomhall must have reached England after 1812 since they were not included in the sale of 1816 . 
lateral folds stemming from the shoulder pins swing slightly outward only in correspondence with the raised skirt and presumably because of it (P1. 56, c). The neckline, as in the Hope maiden, follows the collarbones and adheres closely to the chest. ${ }^{23}$ The back (Pl. 55, b) repeats somewhat perfunctorily the pattern of the front: the kolpos has disappeared under the overfold and the skirt looks more closely gathered, but these are only minor variations. A certain superficiality of carving (especially in the skirt grooves) suggests that the rear was not an important aspect of the statue, but the undercutting of the apoptygma folds is conscientiously carried out; the cloth slightly models the spinal furrow and the buttocks are suggested.

The Elgin torso must date early in the Severe period; the folds are still reminiscent of Archaic renderings, and especially so is the strong anatomical treatment of the right leg. The simplicity of the apoptygma without modeling folds may likewise be partly attributed to chronology rather than solely to taste. But the general cast of the composition is definitely Severe in its block-like structure, the emphasis on verticals and horizontals, the large rectangular pattern of the apoptygma panels of comparable width both front and back. Next to her the Hope maiden appears not merely simple but mannered, and her overfold looks remarkably de-emphasized; her stylistic vocabulary is the same, but the intonation is different.

In summary: the Elgin Peplophoros is a remarkable Greek original of the years around 475 B.C. Among other statues of the same type she stands out because of her greater simplicity and tectonic qualities. Since the Copenhagen and Castel Sant' Angelo statues are generally accepted as copies rather than originals, the California torso becomes an important contemporary testimony of the type-in marble as contrasted with the large production in bronze, and free standing as contrasted with the architectural examples. The Hope Peplophoros was obviously inspired by a similar prototype, but it cannot be considered a true copy; several incongruities in the rendering and a certain mannerism of conception and detail suggest that it was created during the first century B.C., at a time when the Severe style enjoyed a strong revival in GraecoRoman artistic circles. If this evaluation is correct, we may have lost an item from our list of copies of early fifth century works, but we have gained an important document for our evaluation of Classicizing currents which exploited not only the decorativeness of the Archaic and the full-blown opulence of the Classical, but also, and more than is generally realized, the heavy simplicity of the Severe style.

\section{BRUnilde Sismondo Ridgway}

Bryn Mawr College

${ }^{23}$ For a similar rendering of the neckline see, e.g., the Peplophoros from Xanthos, Br. Mus. B 317 (above, note 13). This plain treatment of the neckline is somewhat uncommon, the more popular form including a small fold between the breasts, with a consequent zigzag edge to the opening, as in the second Peplophoros from Xanthos, B 318. The Lycian statues compare with the Elgin torso also in the waved lower edges of their apoptygmas, which are, however, more enlivened by folds. 


\section{PLATE 54}
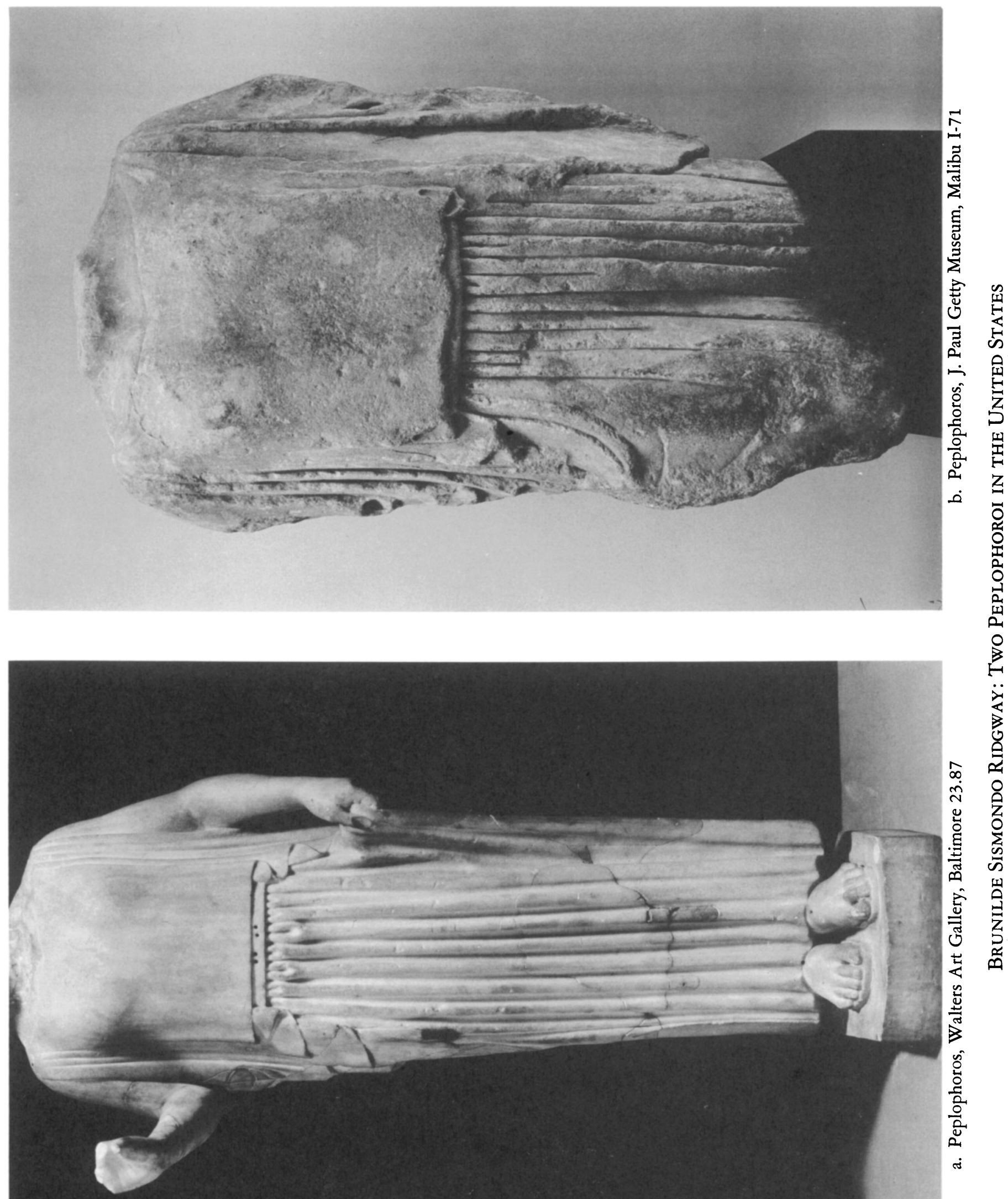
PLATE 55

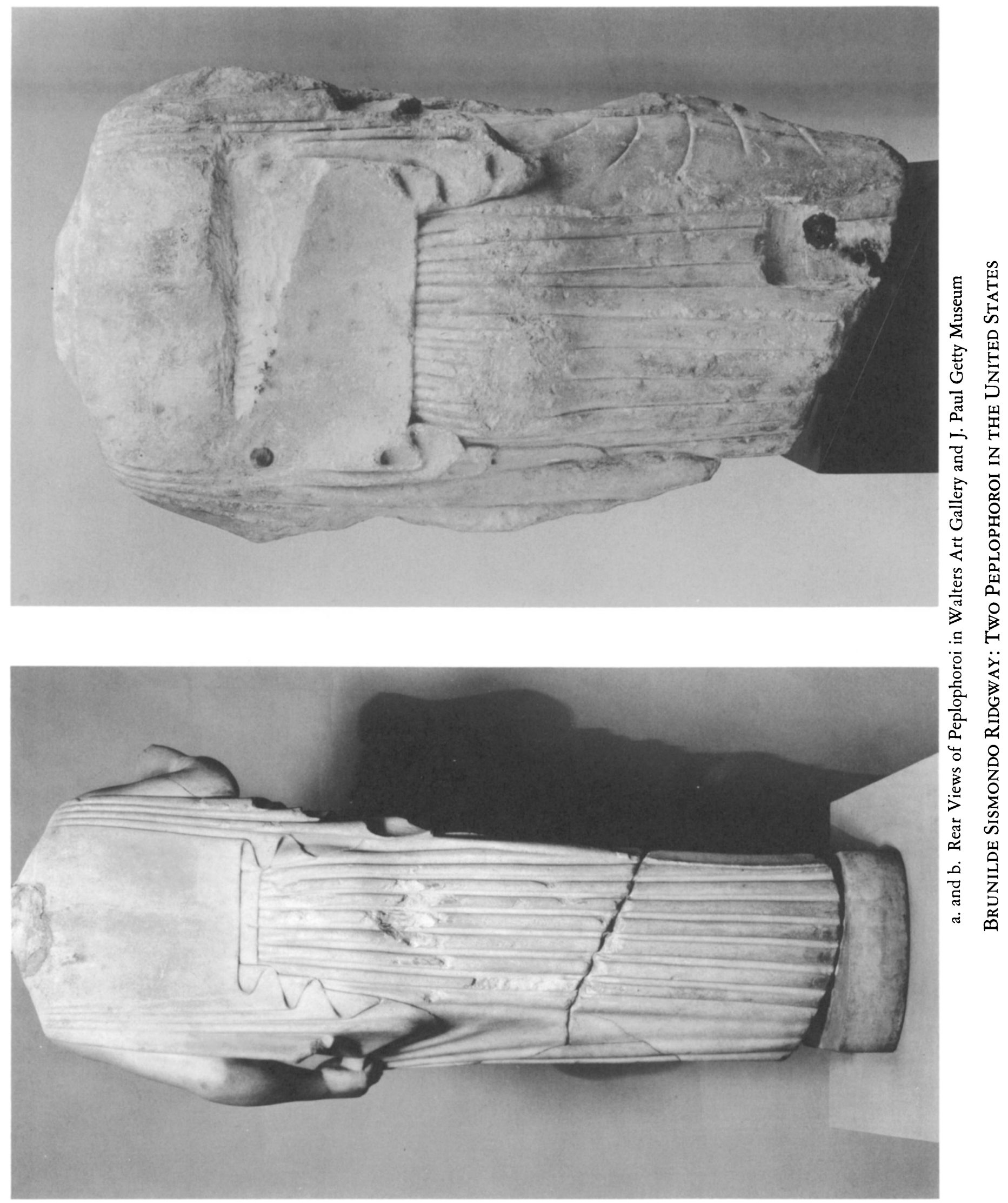


PLATE 56
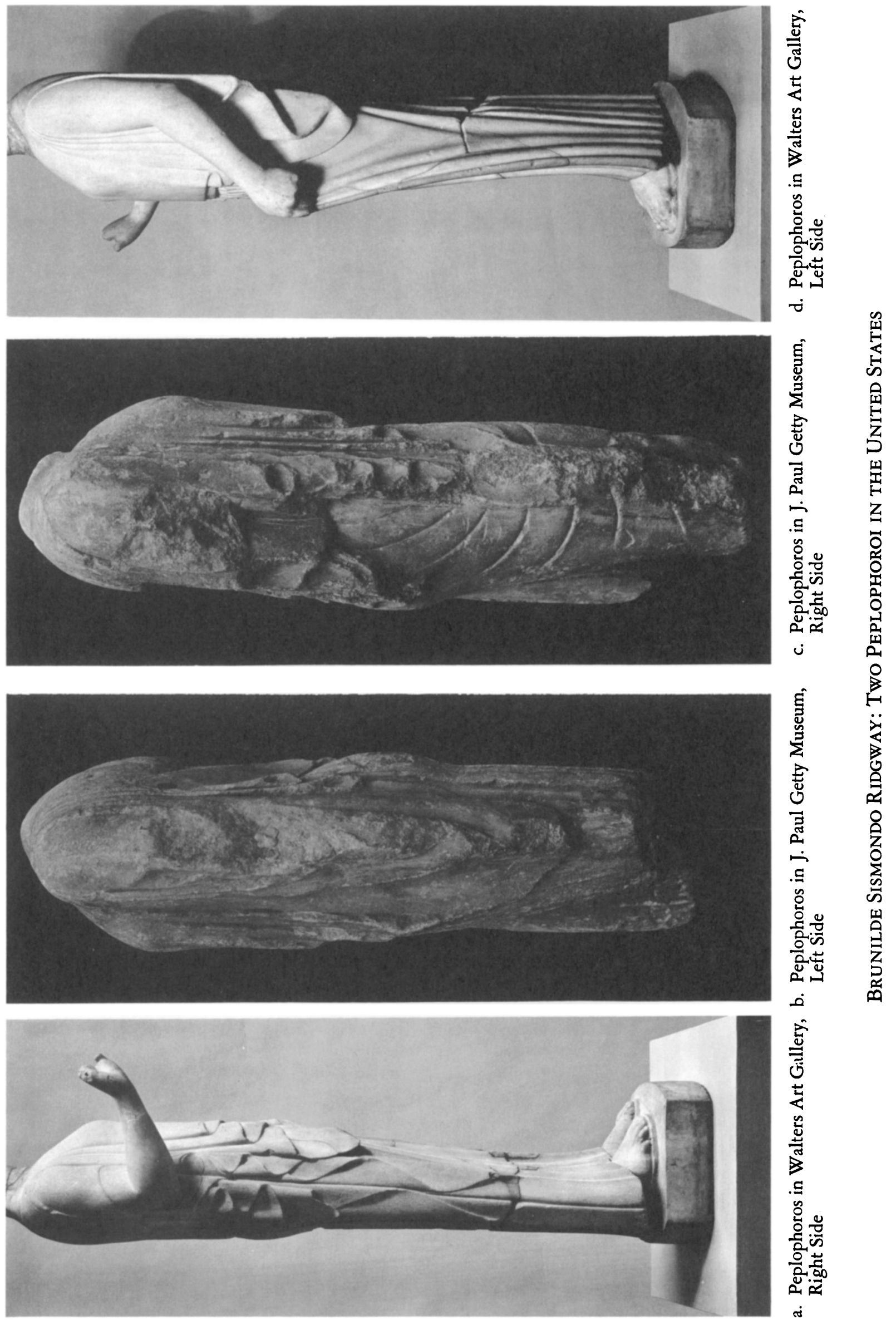


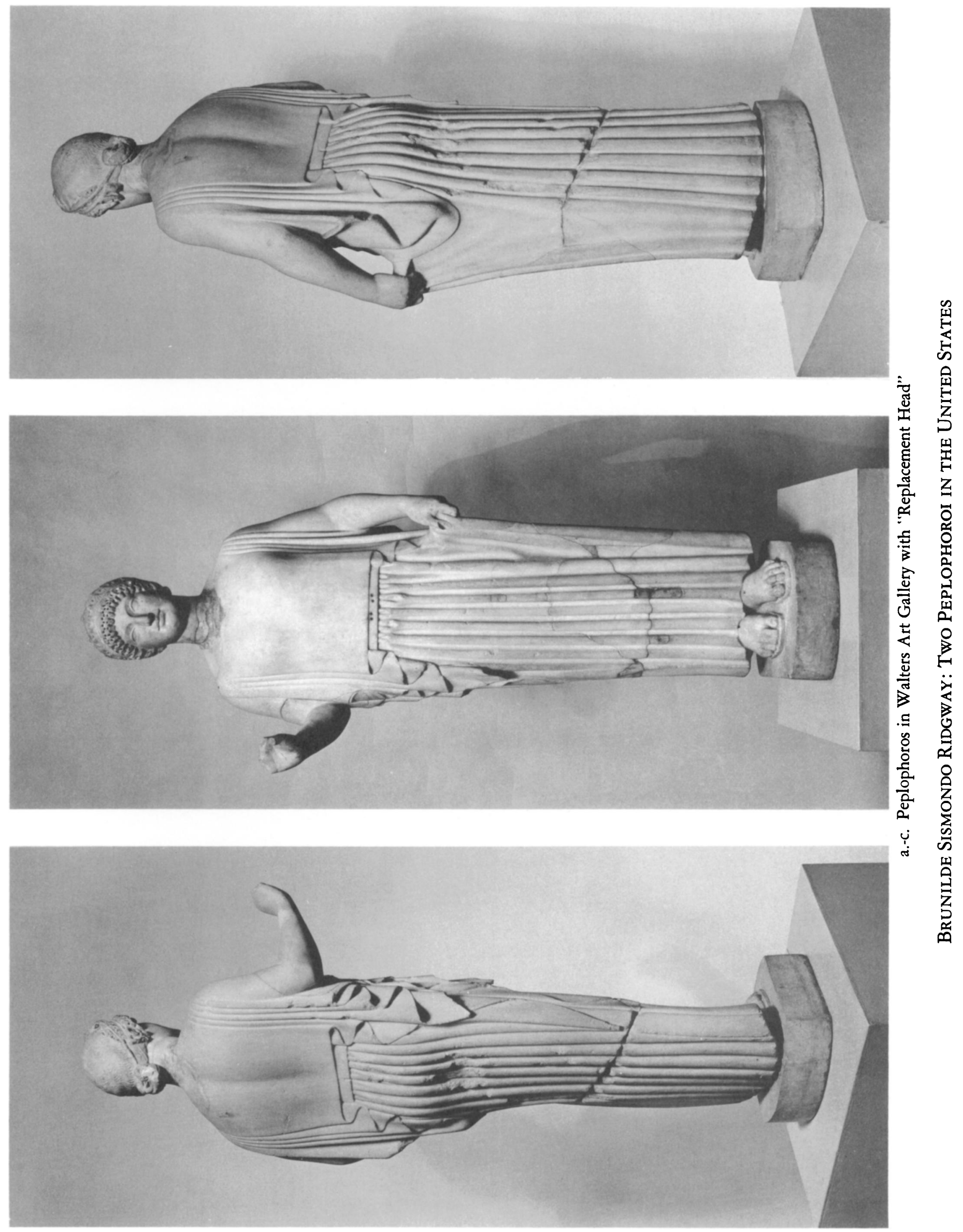

